\title{
The Pluralisation of Family Life: Implications for Preschool Education
}

MOJCA KOvač ŠEBART ${ }^{* 1}$ AND ROMAN KuHAR ${ }^{2}$

$\approx$ The article takes as its starting point the public debate about the newly proposed Family Code in Slovenia in 2009. Inter alia, the Code introduced a new, inclusive definition of the family in accordance with the contemporary pluralisation of family life. This raised a number of questions about how - if at all - various families are addressed in the process of preschool education in public preschools in Slovenia. We maintain that the family is the child's most important frame of reference. It is therefore necessary for the preschool community to respect family plurality and treat it as such in everyday life and work. In addition, preschool teachers and preschool teacher assistants are bound by the formal framework and the current curriculum, which specifies that children in preschools must be acquainted with various forms of families and family communities. This also implies that parents - despite their right to educate their children in accordance with their religious and philosophical convictions - have no right to interfere in the educational process and insist on their particular values, such as the demand that some family forms remain unmentioned.

Keywords: family, pluralisation of family life, preschool, curriculum

1 *Corresponding Author. University of Ljubljana, Faculty of Arts, Slovenia; mojca.kovac-sebart@ guest.arnes.si.

2 University of Ljubljana, Faculty of Arts, Slovenia. 


\section{Pluralizacija družinskega življenja: implikacije za predšolsko vzgojo}

Mojca Kovač ŠEbart In Roman Kuhar

$\propto V$ izhodišče članka postavljava javno razpravo o novem predlogu Družinskega zakonika v Sloveniji leta 2009. Omenjeni zakon je skladno s procesom pluralizacije družinskega življenja vpeljal novo, inkluzivno definicijo družine. To je vzpostavilo vrsto vprašanj o tem, kako in ali sploh so različne oblike družin naslovljene v predšolski vzgoji in izobraževanju v javnih šolah v Sloveniji. Družino razumeva kot otrokovo najpomembnejšo referenčno točko, zato je pomembno, da tisti, ki delujejo v predšolski vzgoji, spoštujejo pluralnost družinskih oblik in da različne družinske oblike na tak način tudi naslavljajo pri svojem delu. Poleg tega vzgojitelje in pomočnike vzgojiteljev k temu zavezujeta formalni okvir in obstoječi kurikulum, ki določa, da se morajo otroci seznanjati z različnimi oblikami družin in družinskih skupnosti. To hkrati pomeni, da starši - kljub pravici, da svoje otroke vzgajajo skladno $s$ svojimi verskimi in filozofskimi prepričanji - nimajo pravice posegati $\mathrm{v}$ izobraževalni proces in vztrajati pri svojih partikularnih vrednotah, kot je na primer zahteva, da določene oblike družin niso omenjene.

Ključne besede: družina, pluralizacija družinskega življenja, predšolsko izobraževanje, kurikulum 


\section{Introduction}

In September 2009, the Ministry of Labour, Family and Social Affairs presented the new Family Code to the public. It was intended to replace the more-than-thirty-year-old (and thus somewhat outdated) Marriage and Family Relations Act (Zakon o zakonski zvezi in družinskih razmerjih, 1976). Although the Family Code contained over 300 articles and regulated a relatively wide area of family life and partnerships, the real causes of disagreement during the public debate were the three articles that opened adoption to same-sex couples and introduced marriage equality and a new, inclusive definition of the family into Slovenian legislation. Legally and, most importantly, symbolically, the definition encompassed various forms of families and included social parenting in addition to biological parenting. The new definition thus shifted from "blood" to "care": that which establishes a family relationship is a relationship of care between a child and an adult (Kogovšek, 2010; Rajgelj, 2010). The Family Code was passed by Parliament in September 2011, but it was rejected in a nationwide referendum in March 2012 (Kuhar, 2015).

The public debate over the Family Code explored a wide range of relevant issues; for instance, the question about how - if at all - public preschools and schools address the process of the pluralisation of family life. Due to the possibility of gay and lesbian adoption, same-sex families were particularly emphasised. The first systematic research study to investigate the question (Tuš Špilak, 2014a; Tuš Špilak, 2014b), which involved 569 Slovenian preschool teachers and preschool teacher assistants (hereafter referred to as educators), demonstrated that almost $68 \%$ of the respondents do not mention same-sex families when talking about different families. The respondents most frequently stated that they do not talk about these families because there are no children from such families in their preschool group (53\%), because children would not understand it (13\%), and because they do not possess sufficient information on the issue $(7.4 \%)$. As many as $7 \%$ believe that such a family is not a real family, $6 \%$ said that parents would disagree if they talked about it with the children, and a little over $5 \%$ believe that the Preschool Curriculum does not require it. Some $14 \%$ of the respondents said that they would only discuss same-sex families in preschool if the head teacher agreed, and $13 \%$ would accept a demand of parents that same-sex families should not be talked about in preschool.

These figures represent the point of departure for our article, which considers the relationship between formal provisions and the professional autonomy of educators, an issue that is directly related to education in public preschools in Slovenia. We will mainly be interested in discussions about families, 
and in educational actions that formally oblige educators during the process of preschool education when dealing with this question.

Our assumption is that preschools are public educational institutions that do not function in an empty space; rather, their frames of functioning are defined by the Constitution, legal acts, curricular documents, etc. Professional autonomous actions are, therefore, not independent of the binding formal framework; quite the contrary, formal provisions protect participants in preschool education from professional autonomy turning into educators' unprofessional arbitrariness, on the one hand, and from parents, preschool management, state ministries or anybody else interfering in professional decisions, on the other. In this sense, such provisions are far from being an obstacle to professional work in preschools, which seems to be quite a common presupposition (see, e.g., Batistič-Zorec \& Hočevar, 2012; Hočevar, Kovač Šebart \& Štefanc, 2013).

\section{The formal framework and the planning and conducting of preschool education in public preschools in Slovenia}

The formal (and ethical) value framework of how public preschools function is primarily provided by the Constitution of the Republic of Slovenia (Ustava Republike Slovenije [1991] 2011, hereafter referred to as Constitution), which contains a provision stating that, in Slovenia, everyone is equal before the law, and that everyone shall be guaranteed equal human rights and fundamental freedoms irrespective of any personal circumstance (Article 14). Human rights and fundamental freedoms can only be limited by the rights of others (Article 15), while everyone has the right to personal dignity and safety (Article 34) and to the inviolability of physical and mental integrity, as well as privacy and personality rights (Article 35).

Article 56 of the Constitution is also pertinent to the issue examined here. It states that children enjoy special protection and care and are granted human rights and fundamental freedoms consistent with their age and maturity. The protection of personal data, the right of access to the collected personal data that relate to an individual, and the right to judicial protection in the event of any abuse of such data are guaranteed by Article 38 of the Constitution.

The quoted constitutional articles demonstrate that the concept of human rights (and duties) is the fundamental legal and ethical norm in Slovenia (Kovač Šebart, 2013; Kovač Šebart \& Krek, 2009). From the aspect of legality and legitimacy, this concept is the normative basis that must be followed during education in public educational institutions (for more on this, see Kovač Šebart, 
2002; Kovač Šebart, 2013; Kovač Šebart \& Krek, 2009; Kovač Šebart \& Krek, 2010). Public educational institutions must, then, orient their participants in such a way that the value guidance derived from rights imposes duties and actions that embody respect for every person, regardless of the differences between people.

Respect for human rights is the support, safeguard and corrective that enables educators to avoid arbitrary, albeit inadvertent actions based on personal, particular value judgements or on individual parents' or children's particular values. It is the professional duty of educators not to let such views hinder the equal treatment of all children (Zaviršek \& Sobočan, 2012). They must insist on the implementation of the principle of non-discrimination and act in accordance with the norm of respect for everybody, which is a professional duty in relation to others. This is the limit to the implementation of the demands originating in particular convictions (Kovač Šebart, 2013; Kovač Šebart \& Krek, 2009), even when, for instance, they are put forward by parents.

In view of the latter, Article 54 of the Constitution is relevant, stating that parents have the right and duty to maintain, educate and raise their children; furthermore, Article 41 stipulates that parents have the right to provide their children with a religious and moral upbringing in accordance with their own beliefs (ibid.). In Slovenia, educational institutions - and, thereby, educators - are bound by Article 2 of Protocol No. 1 to the European Convention for the Protection of Human Rights and Fundamental Freedoms (1950), specifying that, in the exercise of any functions that the state assumes in relation to education, it must respect the right of parents to ensure such education that conforms to their own religious and philosophical convictions.

Decisions by the European Court of Human Rights and the European Commission on Human Rights have developed the general interpretations of the article: in public educational institutions, the state is not obliged to provide education in accordance with parents' wishes; however, it must enable parents to find private preschools and schools where their children will be given such education, but the state itself is not obliged to either establish or finance them (Kodelja, 1995). It is important to emphasise that public educational institutions in Slovenia must not impose on children or require them to identify with values towards which individuals adopt different attitudes. Quite the opposite: they must express such differences very clearly and allow for their coexistence (Kovač Šebart \& Krek, 2009), while educational content must be imparted in an objective, critical and pluralist way.

Respect for human rights as a norm, therefore, does not require public preschools in Slovenia to yield to parents' demands that educators should not 
address certain topics because they express viewpoints that contradict the parents' convictions. Educators, likewise, cannot overlook the formal framework of norms, principles and goals, not even in the name of professional autonomy. Excuses such as that they will not address an issue because they do not know how to deal with it, or that they are worried about not having enough knowledge, or that they will be accused of indoctrinating children, or that the institution's management or other educators are not keen on the issue, etc. (Zaviršek \& Sobočan, 2012) do not justify the exclusion of such topics from (pre)school work. Consequently, discussion about an issue in public preschools may objectively sidestep certain particular values and parents' beliefs, and during such an educational process some children will be morally distressed. Respect for human rights and duties as a common value framework requires the educator not to impose or demand the adoption of any viewpoint about which different groups of people hold different beliefs. The decision on how to address a topic that is related to particular convictions belongs to the educator's professional autonomy. The choice of the method, however, cannot bypass the formal framework, which insists on the presentation of differences and respect for different views.

\section{Legislation and the curriculum}

Article 2 of the Organisation and Financing of Education Act ( Zakon o organizaciji in financiranju vzgoje in izobraževanja [1996] 2007), which is the framework act in the area of education, includes the following aims of the education system in Slovenia: ensuring the individual optimum development regardless of his/her personal circumstances, educating for mutual tolerance, developing equal opportunities for both genders and an awareness of the equality of genders, respect for diversity and cooperation with others, respect for children's and human rights and fundamental freedoms, developing abilities to live in a democratic society, and encouraging an awareness of the individual's integrity.

Logically following the constitutional norms granting everybody equal rights and fundamental freedoms regardless of any personal circumstances, Article 3 of the Preschool Education Act (Zakon o vrtcih, [1996] 2005) also specifies the principles to which education in public preschools must adhere. These are, among others, the principles of democracy, plurality, autonomy, professionalism and responsibility of employees, equal rights for children and parents, diversity among children, the right to choose and the right to difference.

The Preschool Curriculum (Kurikulum za vrtce, 1999; hereafter referred to as the Curriculum) includes the following principles: the principle of equal 
opportunities, the principle of respect for diversity among children, and the principles of multiculturalism, democracy and pluralism. The principles complement the constitutional and statutory norms presented above, but are here related to broader content norms that educators in preschools must follow.

Needless to say, the principles must not remain a dead letter; rather, they must be realised in the life and work of each preschool. They express the general guidelines and conditions for the successful methodical execution of educational activity in terms of its goals, processes and content. At the same time, they require educators to reflect upon their realisation when planning, conducting and evaluating educational work.

In addition, the Curriculum (1999) defines goals and activities in the areas of movement, language, art, society, nature and mathematics. The goals specified within each individual activity area are the framework in which content and activities provide working proposals for educators. The goal-oriented strategy of curricular planning - in combination with the process/developmental strategy, which is the expert basis for planning content and activities in preschool education in public preschools in Slovenia - is based on the assumption that specific goals in individual activity areas are the curricular starting points for planning preschool education. According to France Strmčnik (2001, p. 203), goals direct expert decisions, although they are not themselves such decisions. A great number of decisions relate to specific educational situations, which cannot be predicted in advance or from the outside. Nevertheless, educators' decisions demonstrate better quality and greater consistency if they are directed by goals.

Goals are defined at different levels of curricular planning (state, institutional, individual) and in different documents, both legal/formal and curricular (Kelly, 2009). In Slovenia, preschool education at the state level is primarily defined by the aims and goals of education as specified in the Organisation and Financing of Education Act (Zakon o organizaciji in financiranju vzgoje in izobraževanja, [1996] 2007, Article 2), by the goals of preschool education as specified in the Preschool Education Act (Zakon o vrtcih, [1996] 2005, Article 4) and by the goals and objectives as specified in the Curriculum (Kurikulum za vrtce, 1999), for the programme of preschool education as a whole and for individual preschool education areas.

Related to the goals are content and activities that are interrelated, developed and complemented at the level of the (pre)school curriculum (Kurikulum za vrtce, 1999). When choosing content, educators follow the principles and goals that are presented above, taking account of developmental-psychological and other characteristics relevant to the educational process, as well as children's interests. Furthermore, the provision in Article 92 of the Organisation 
and Financing of Education Act (Zakon o organizaciji in financiranju vzgoje in izobraževanja, [1991] 2007) is also important to the planning, execution and evaluation of the educational process, requiring educators to carry out educational work in accordance with the law and valid programmes in an objective, critical and pluralist, as well as professionally autonomous, manner.

Educators are bound to transmit knowledge based on science, scientific findings and scientific argumentation. This formal norm nevertheless recognises that public educational institutions are not neutral in the sense of being without values; rather, they rely on the values that contemporary society perceives as shared. At the same time, public educational institutions must allow for plurality when particular values, beliefs and convictions are concerned, but only as long as individuals do not overstep the boundaries of tolerance and constitutionally guaranteed human rights. Plurality is also binding when educators select learning content.

\section{The selection of content: The case of the family and vari- ous family forms}

The described norms and principles, and the ways in which they affect how preschool education in public preschools is planned and conducted, will be illustrated with the case of the family. The family forms part of the content that the Curriculum (Kurikulum za vrtce, 1999) mainly integrates into the activity area of society. This is the same for both age groups, and the Curriculum includes the following as one of the goals in the area of society: "the child learns about various forms of families and family communities" (Kurikulum za vrtce, 1999).

In the area of society, the goals specified that are related to the attention given to the family define that children should experience preschool as an environment, "with equal opportunities for participation in activities and everyday life, regardless of gender, physical and mental constitution, nationality, cultural origin, religion, etc.". Moreover, children should learn about themselves and others, including "learning about differences between the habits of our culture and other cultures, and between different social groups". Finally, the goals also define "learning about intercultural and other differences" and "encouraging sensitivity to the ethical dimension of difference" (Kurikulum za vrtce, 1999, p. 50).

The Curriculum goes on to define nineteen goals related to the area of society whose content involve gaining experience and accepting difference, understanding the equality of everybody, the need for people to cooperate, challenging gender-related stereotypes, developing abilities to establish friendships, understanding rules for desirable behaviour based on the non-infringement 
of the rights of others, etc. The 19 goals of the Curriculum also include the one specifying that the child must learn about "various forms of families and family communities" (Kurikulum za vrtce, 1999, pp. 50-51).

The goals and objectives just presented provide the basis for planning, realising and evaluating the programme of preschool education. We presume they can be attained through a planned realisation of the programme. Planning activity considerations are one of the key steps of individual curricular planning. Educators are autonomous in this respect, but the Curriculum provides them with sufficient support, listing examples of activities for both age groups.

Examples of activities for children aged between one and three years that directly relate to the family include: talking about family members and events at home, if the child wants to talk about them; learning about different living habits and forms of family and social life in different cultures and social groups, which acquaints the child with differences between people; and changing gender-specific roles (for example, playing at doing different jobs, housework and suchlike) (Kurikulum za vrtce, 1999, p. 52).

Examples of activities for children aged between three and six years that relate to the family include: talking about home, family and the child's experiences, if the child wants to talk about them or starts the conversation him/ herself; learning about different forms of family communities; acquiring experience by changing gender-specific roles; acquiring social skills, which includes understanding and taking account of the needs, emotions and convictions of others; and other activities, such as discussion about prejudices and stereotypes (Kurikulum za vrtce, 1999, pp. 51-54).

In addition to goals, objectives and examples of activities, the Curriculum specifically defines the role of adults in achieving the goals in individual areas. In the area of society, it states that children become acquainted with their restrictions and the limits to acceptable behaviour, which primarily implies non-restriction of others. Preschools should be an environment in which children are confirmed as individuals and have the possibility of developing a sense of cooperation (Kurikulum za vrtce, 1999). Educators must enable children to accept rules critically, cooperate in their adjustment, and "cooperate in the creation of a culture of coexistence in differences and diversity. It must be guaranteed that children experience preschool as an environment with equal opportunities for participation in activities and everyday life regardless of gender, physical and mental constitution, nationality, cultural origin, religion and other circumstances, and also as an environment in which they can develop a safe gender identity" (Kurikulum za vrtce, 1999, p. 54). The Curriculum also states that adults should facilitate connections between preschools and children's 
families, manage the information flow between children and families, and, in the first age group, encourage the presence of family members in the group (Kurikulum za vrtce, 1999, p. 50). This means that educators "know the cultures of the children in their groups and respect the families' orientations" (Kurikulum za vrtce, 1999, p. 50).

It is important that adults do not allow "comments, references and actions that stereotype people. They accept differences among people without exaggeration, and avoid comparisons when observing individual children" (Kurikulum za vrtce, 1999, p. 55). The document also clearly specifies that "preschools must not isolate themselves from the environment of their children and their experiential worlds; similarly, they must not use activities to transmit into preschools differences that could result in children not feeling equal" (Kurikulum za vrtce, 1999, p. 55). Furthermore, the Curriculum also states that adults must ensure corners in playrooms that are suitably equipped for social life, "including such books that can help children to become acquainted with differences between people, intercultural differences and historical changes" (Kurikulum za vrtce, 1999, p. 55).

Thus, there should be no dilemma (either formal, professional or ethical) for educators in public educational institutions: in preschools (in both age groups) they address content that relates to families and various family forms. Children learn about differences and similarities between people, and about their equality. The language of instruction is inclusive (e.g., talking about parents and a parent). In so doing, educators follow the principle of objective, critical and pluralist education.

What does this mean for the autonomous professional selection of content? It means that, in addition to the nuclear family model (mother + father + child/ren), educators must not avoid addressing families that differ from the nuclear model: one-parent families, reorganised families (families in which at least one of the partners has had an earlier family), extended families (families with at least three generations living together: children, parents, grandparents), same-sex families (families in which both parents are the same sex), as well as foster families, adoptive families, and so on. The key emphasis is on the "form", as differences from one model to another do not imply a difference in terms of the child's security and the wellbeing of family life. It is important to underline this, as the studies mentioned at the beginning of this article (Tuš Špilak, 2014a; Tuš Špilak, 2014b) concur with Tanja Rener (2006), who stresses that the idea of the nuclear family has been so overwhelmingly present in the collective imaginaries of western culture for decades (at least since the 1950s) that other family forms are defined in relation to that form: frequently as unusual, deviant or 
even pathological, although such differentiation has no scientific basis in terms of the child's wellbeing. The research on educators in Slovenian preschools did in fact point to significant remnants of collective imaginaries, which appear in the form of more or less hidden prejudices towards homosexuals and their families. Every second respondent in the research thought that a child needs a father and a mother for optimum development.

Although the majority may still claim, despite this opinion, that they do not discriminate against children from other types of families, their views are likely to be reflected in the educational process and in the attitude towards children and parents from families differing from the nuclear model.

It is, therefore, very important that the Curriculum (Kurikulum za vrtce, 1999) clearly states that educators must select content that demonstrates the existence of different family types and lifestyles, and that they must present the content in a way that avoids hierarchising different family forms. This means that, when discussing families, they must not position one single family form as the norm, despite the fact that the majority of the children - or even all of them - may live in such a family. Such positioning would, at the very start, self-evidently imply that, for instance, the difference between one-parent and nuclear families means a deficiency of the former in comparison with the latter ("real"); thus, such a family is not addressed equally from the very beginning. Learning about one (dominant) family type or only those types of families in which children in the group live would disable the achievement of the Curriculum (Kurikulum za vrtce, 1999) objective that requires children to become acquainted with various family forms. Sensitisation to the process of the pluralisation of family life is important from at least two perspectives. Firstly, the presented family models must reflect the family reality of all of the children in a preschool group. Only then is it possible to ensure an inclusive and safe environment in which the child will recognise her/his own experience of the family (Oliveira-Formosinho, 2009). Secondly, it is important for children to become acquainted with other family forms that are not their own, even though they may not (yet) see them in their immediate environment. It would be wrong, then, not to address, for example, adoptive families only because there is no child from such a family in the group.

It is also important to draw attention to the unacceptable approach that outwardly follows the curriculum goal of learning about different families and family communities, but which is, in fact, exclusive, because it devotes the majority of time when debating, playing, reading books, etc. to the nuclear family with the observation that "there are also other types of families" remaining nothing but a footnote. This approach is based on a hierarchical discussion of 
families, where the statistically dominant family model becomes the valuedominant family-life form. If we recognise the fact that the issue of the family permeates practically everything that occurs in preschools, it is important for educators in everyday actions (not only when addressing families in the area of society) to pay attention to the diversity of family life, regardless of their personal preferences or viewpoints.

Each child comes to preschool from a family environment and returns to it. The family belongs to the cultural phenomena that really concern each child directly and subjectively (Zaviršek \& Sobočan, 2012). Consequently, it is important that preschool reality should respect family plurality and consistently address it as such. If children and adults in preschools "are not familiar with differences between family forms, or if adults purposefully ignore them or talk about them derogatorily, the differences may become a source of prejudices, due to which some children become targets of various types of violence or discrimination" (Zaviršek \& Sobočan, 2012, p. 102). Moreover, prejudices harm all of the participants in the educational process, and this concerns learning content, educational actions and everyday life in preschools. As we have seen, educators are formally bound to create the conditions for an expression of children's differences that does not hierarchise, but rather builds on equality, on the levels of content, activities and materials. At the same time, educational work must be conducted in an objective, critical and pluralist manner. The Curriculum unambiguously states that public preschools must provide children with experience and knowledge regarding the diversity of the world, since this is the only way for differences between children to be taken into account during the educational process (Zaviršek \& Sobočan 2012).

In view of the above, and in accordance with the presented formal and professional frameworks, educators must employ a definition of the family that is sufficiently differentiating and, at the same time, inclusive and non-discriminatory. Accordingly, they must include the forms and ways of family life that actually exist in society without making ideological judgements differentiating between them or putting one of them in the position of the norm, with the other forms representing a mere deviation from the norm (Rener, 2006). One of the possible outlines is provided by the official definition of the family in Slovenian legislation, stating that the family is "a living community of parents and children, which enjoys special protection because of the interest of children" (Zakon o zakonski zvezi in družinskih razmerjih, Article 2, [1976] 2004). This definition is sufficiently inclusive and differentiating, under two conditions: (1) if "parents" are not understood in the merely traditional sense of biological parents, which would exclude all social parents who actually perform the role of parents but are 
not the children's biological parents; and (2) if "parents" are not understood as only two parents, which would exclude (at least) one-parent families.

There are fewer doubts with the 1994 definition of the family adopted by the United Nations on the occasion of the International Year of the Family and prepared by a group of family experts headed by Wilfried Dumon from the Catholic University of Leuven (Belgium): "Family is at least one (adult) person or a group of persons which cares for a child and is regarded as a family under the legislation and practice of a State" (Rener, 2006, p. 16). This so-called inclusive definition of the family has a relationship of care between an adult and a child as the basic premise of family life, whereby it is irrelevant whether the adult is the child's biological parent or not. This definition encompasses the widest possible family plurality as the principal characteristic of contemporary family life, and this is what educators' work regarding families should be like in preschools (i.e., inclusive). What is more, it is imperative that the family is not an isolated topic that is only discussed on a specified day, as children bring their family lives to preschools daily.

\section{Conclusion}

The family is the child's most important frame of reference, so it is not surprising that the formal framework that regulates educational work in Slovenian preschools states - to simplify matters a little - that nobody who is affected by preschool work should be exposed due to her/his family's characteristics. Everybody must be treated equally, without emphasising particularities. However, this does not mean, as we have said above, that differences should be erased or intentionally ignored; it simply means that differences should not be hierarchised and nobody should be excluded. Families are not something static; they are not, in Morgan's (1999) words, a noun, but rather a verb: families are forever "made" and "lived". As active subjects, we also create the reality of educational institutions, which must respect family plurality. In this respect, educators are faced with very clear demands: "In preschool, children must undergo concrete experiences in realising fundamental human rights and democratic principles, in appreciating the child as an individual, and in respecting privacy. At the same time, everyday life, work and activities in preschool must enable the development of a sense of security and social belonging, which is based on the idea of equality and non-discrimination (regarding gender, social and cultural background, religion, physical constitution, etc.). Therefore, children must acquire basic rules of behaviour and communication that originate in the conception of the individual's freedom as non-restriction of the freedom 
of others. Children must also have a wide variety of possibilities of developing critical minds, personal decisions and autonomous judgements" (Kurikulum za vrtce, 1999, p. 49). We are fully aware that our analysis of the formal framework is only one of the factors that contributes to an inclusive and non-discriminatory preschool education in public preschools. Although a good knowledge of the formal framework is of key importance, there are other factors that should also be taken into consideration, such as the reasons why the goal of "learning about various forms of families and family communities" is not met and what practical tools preschool teachers have in order to reach this goal. All of these aspects need further research, although some tools - partly due to the Family Code policy debate in Slovenia - have already been created/translated in the past few years in Slovenia. ${ }^{3}$

Content, activities and educational actions in preschools concerning the family (as well as other topics) must, therefore, be well thought through and carefully planned. Having said that, we should not forget that the formal framework of norms, principles and goals, as presented here, is binding on educators, while the latter are, at the same time, professionally autonomous in their choice of content and didactic strategies.

\section{References}

Batistič-Zorec, M., \& Hočevar, A. (2012). Planning and evaluating educational work in Slovene preschools. CEPS Journal, 2(2), 109-128.

Hočevar, A., Kovač Šebart, M., \& Štefanc, D. (2013). Curriculum planning and the concept of participation in the Reggio Emilia pedagogical approach. European Early Childhood Education Research Journal, 21(4), 476-488.

Kelly, A. V. (1989). The Curriculum: Theory and Practice. London: PCP.

Kodelja, Z. (1995). Laična šola: pro et contra [Secular School: Pro et Contra]. Ljubljana: Mladinska knjiga.

Kovač Šebart, M. (2002). Samopodobe šole: konceptualizacija devetletke [Self-image of the School: Conceptualization of Primary School]. Ljubljana: Center za študij edukacijskih strategij, Pedagoška fakulteta, Univerza v Ljubljani.

Kovač Šebart, M. (2013). Kaj v javno vzgojno-izobraževalno ustanovo prinaša zahteva po spoštovanju

3 The book by Darja Zavišrek and Ana M. Sobočan Mavrične družine grejo $v$ šolo: Perspektive otrok, staršev in učiteljic (FSD, 2012) offers a good overview of the issues children face in non-normative family settings. The second part of the book offers (preschool) teachers specific examples of how to address family diversity in kindergartens and schools. Among children's picture books, we recommend Mary Hoffman's Velika knjiga o družinah (Didakta, 2010), which is an excellent source for addressing family plurality "through children's eyes". Finally, there are two children's picture books that specifically address same-sex families: In s Tango smo trije (J. Richardson and P. Parnell, Modrijan, 2010) and Sosedje in prijatelji (Lawrence Schimel, Škuc Lambda, 2008). 
vrednotnega okvira človekovih pravic? [What Does the Demand for the Respect of the Value Framework of Human Rights Bring to Public Educational Institutions?]. Sodobna pedagogika, 64(2), $32-47$.

Kovač Šebart, M., \& Krek, J. (2009). Vzgojna zasnova javne šole [Educational Design of Public School]. Ljubljana: Center za študij edukacijskih strategij, Pedagoška fakulteta, Univerza v Ljubljani. Kovač Šebart, M., \& Krek, J. (2010). The public school, values and educational discourse. Pardubice: University of Pardubice.

Kogovšek, N. (2010). Iskanje pravnih razlogov za priznanje enakih pravic istospolnim partnerjem in njihovim družinam [Looking for Legal Reasons For Recognising Equal Rights to Same-sex Partners and Their Families]. Socialno delo, 49(5-6), 319-330.

Kramar, M. (1994). Načrtovanje in priprava izobraževalno-vzgojnega procesa v šoli [Planning and Preparation of Educational Process at School]. Nova Gorica: Educa.

Kramar, M. (2009). Pouk [Classes]. Nova Gorica: Educa, Melior.

Kuhar, R. (2015). Playing With Science: sexual citizenship and the Roman Catholic Church counternarratives in Slovenia and Croatia. Women's studies international forum, 49(2), 84-92.

Kurikulum za vrtce [Preschool Curriculum] (1999). Retrieved from http://www.zrss.si/ pdf/050711123045_vrtci_kur.pdf

Morgan, D. H. (1999). Risk and family practices: Accounting for change and fluidity in family life. In E. B. Silva, \& C. Smart (Eds.), The New Family? (pp. 13-30). London: Sage.

Oliveira-Formosinho, J. (2009). Togetherness and play under the same roof: children's perceptions about families. European Early Childhood Education Research Journal, 17(2), 233-248.

Protocol no. 1 to the European Convention on Human Rights and Fundamental Freedoms (1950).

Retrieved from http://www.dp-gov.si/fileadmin/dp.gov.si/pageuploads/RAZNO/EKCP_SLV.pdf Rajgelj, B. (2010). Razmerja v istospolnih družinah - kje smo in kam lahko gremo? [Relationships in the Same-sex Families - Where Do We Stand and in Which Direction Can We Move?] Socialno delo, 49(5-6), 305-318.

Rener, T. (2006). Težave s pojmom družine [Troubles with the Term Family]. In T. Rener, M. Sedmak, A. Švab, \& M. Urek (Eds.), Družine in družinsko življenje v Sloveniji (pp. 13-26). Koper: Annales. Strmčnik, F. (2001). Didaktika: osrednje teoretične teme [Didactics: Central Theoretical Topics]. Ljubljana: Znanstveni inštitut Filozofske fakultete.

Strmčnik, F. (2003). Didaktične paradigme, koncepti in strategije [Didactical paradigms, Concepts and Strategies]. Sodobna pedagogika, 54(1), 80-92.

Tuš Špilak, N. (2014a). Queerovski pristop k vzgoji: Primer obravnave pravljice In s Tango smo trije v slovenskih vrtcih [Queer Pedagogy: An Example of a Discussion of the Children's Story “And Tango Makes Three” in Kindergartens in Slovenia]. Družboslovne razprave, 30(75), 65-84.

Tuš Špilak, N. (2014b). Istospolne družine v vrtcih v Sloveniji [Same-sex Families in Kindergartens in Slovenia]. Narobe, 7(29-30), 18-20.

Ustava Republike Slovenije [Constitution of the Republic of Slovenia] [1991] (2011). Retrieved from http://www.us-rs.si/media/ustava_koncna.2013.pdf 
Zaviršek, D., \& Sobočan, A. M. (2012). Mavrične družine grejo v šolo: perspektive otrok, staršev in učiteljic [Rainbow Families go to School: Perspectives of Children, Parents and Teachers]. Ljubljana: Fakulteta za socialno delo.

Zakon o organizaciji in financiranju vzgoje in izobraževanja [Organization and Financing of Education Act] [1996] (2007). Retrieved from http://www.uradni-list.si/1/content?id=78530 Zakon o vrtcih [Preschool Education Act] [1996] (2005). Retrieved from http://www.pisrs.si/Pis.web/ pregledPredpisa?id=ZAKO4589

Zakon o zakonski zvezi in družinskih razmerjih [Marriage and Family Relations Act] [1976] (2004).

Retrieved from http://www.uradni-list.si/1/objava.jsp?urlid=200469\&stevilka=3093

\section{Biographical note}

MoJCA Kovač ŠEBART, PhD, is professor of Sociology of Education at the University of Ljubljana (Faculty of Arts, Department of Educational Sciences). Her research topics include preschool and family education, authority, moral education, multicultural and Roma education, citizenship education, classroom and school culture. She is the author of several books, among others Self-perceptions of school: conceptualizing the 9-year compulsory education in Slovenia (2002, in Slovene language), co-author (with J. Krek) of the The public school, values and educational discourse (2010), co-author (with A. Hočevar) of the Preschool education - some organizational and conceptual dilemmas (2012). She is also (co)author of numerous articles published in internationally recognized journals, among others "Curriculum planning and the concept of participation in the Reggio Emilia pedagogical approach" (2013, European early childhood education research journal), "How to evaluate and judge when the moral-educational dimension of instruction is concerned?" (2015, Review of European studies), "Citizenship education in Slovenia after the formation of the independent state" (2008, Journal für Sozialwissenschaften und ihre Didaktik), "Where East meets West: controversies of textbook publishing in small former communist countries" (2004, Publishing research quarterly).

Roman KuHAR, $\mathrm{PhD}$, is a professor of sociology at the University of Ljubljana (Faculty of Arts, Department of Sociology). His research topics include glbt/queer issues, intolerance and equality, media, citizenship, and sexuality. He is the author of several books, among others Media Construction of Homosexuality (2003), At the Crossroads of Discrimination (2009), co-author (with A. Švab) of The Unbearable Comfort of Privacy (2005) and co-editor (with J. Takács) of Beyond The Pink Curtain: Everyday life of LGBT people 
in Eastern Europe (2007), Doing Families: Gay and Lesbian Family Practices (2011) and (with D. Paternotte) of Anti-gender campaigns in Europe: Mobilizing against equality (Rowman \& Littlefield, 2017). He is an associate coeditor of Social Politics and a board member of Journal of LGBT youth and Družboslovne razprave. 